\title{
Representations of Women in Tudor Historiography: John Bale and the Rhetoric of Exemplarity
}

KRISTA KESSELRING

Summary: The writings of Anne Askew and the Princess Elizabeth have received attention as two of a small number of published works by women in the Tudor period. The lengthy additions and glosses of their editor, John Bale, have garnered much less notice. Bale appropriated these writings for the use of protestant polemic, and presented their authors as exemplary historical agents worthy of emulation by men and women alike. By situating these two women in his apocalyptic rewriting of the past, he created for women a place in the new protestant history of the realm. The struggle of the True and the False Churches provided for Bale a fluid situation in which women might be required to assume behaviours typically labeled masculine; he used these writings, and the sanction of historical precedent; to advocate an active, public role for educated women.

John Bale, a Carmelite friar turned reformer, appropriated the writings of two women for the uses of protestant polemic. These works, Anne Askew's account of the interrogations that would lead to her death at the stake, and the Princess Elizabeth's translation of The Mirror or Glass of the Sinful Soul, have received attention as two of only a small body of published writings by Tudor women. ${ }^{1}$ Bale's own additions to these works have, however, received much less notice. ${ }^{2}$ His introductory comments, "elucidations" and conclusions to these two pieces present their female authors as role models for the emerging protestant cause. But Bale, like his protégé John Foxe, was engaged in a project that extended beyond simple polemic or the description of godly role models. He attempted to construct a new history for England 
and its church. This history drew its materials from the old chronicles, but found its organizing principle in the Revelation of Saint John. Gendered metaphors run through his work, and female allegorical figures personify the polarities of good and evil — the true and the false churches - around which Bale's history is structured. ${ }^{3}$ But actual women also appear as historical actors; in the Examinations of Anne Askew and the Godly Medytacyon of the Christen Sowle, Bale presents both Anne Askew and the Princess Elizabeth as exemplary figures in the continuing struggle of the two churches, and as agents in the unfolding of history as prophesied in the Apocalypse.

Bale's work, much as that of John Foxe, has often been excluded from discussions of Tudor historiography. When it does appear, it is generally dismissed for its historical inaccuracies and blatant bias. ${ }^{4}$ Yet, when we stop looking for signs of modernity in early modern historical writing, or remember the contingency and subjectivity of our own histories, works such as Bale's assume a greater importance. ${ }^{5}$ Bale attempted to reconcile sacred and secular history along protestant lines. He wrote not only to delineate continuities between the past and the present and thus make the Reformation seem less of a novelty, but also to construct a version of the past that explained and contextualized the struggles of the Reformers. ${ }^{6}$ Bale's vision of history was formulated and expressed most cogently in his Image of Both Churches (1545), but its principles and topoi structure permeate all his subsequent works, including the Examinations and the Medytacyon.

Bale's historical thought was often expressed in various forms of life-writing. His Brefe Chronycle concernynge the examinacyon and death of ...Syr J. Oldcastell and Examinations of Anne Askew, both traditionally labeled as martyrologies, and his "auto-biographical" Vocacyon of Johan Bale are perhaps the most obvious examples. ${ }^{7}$ But so, too, do his Actes or unchast examples of the Englysh votaryes and the Acta Romanorum Pontificum trace the origins of various "popish" practices through the lives and actions of various prelates. ${ }^{8}$ His antiquarian treatises provide not only bibliographies of English authors, but also brief biographical descriptions designed to show how the activities of the writers themselves were illustrative of the apocalyptic progress of history. ${ }^{9}$ In many cases, Bale merely lists famous men, and occasionally women, who had struggled for either the true or the false church, but in others he treats his subjects in greater depth and presents them as positive historical agents worthy of emulation.

The provision of these exemplary lives can be seen as a form of conduct literature. ${ }^{10}$ Some scholars, recognizing that prescriptive tex ts do not directly 
describe reality, have set off in search of the parameters of women's lived experience. Such work is essential, but must be combined with a reinvigorated approach to written texts. ${ }^{11}$ For while prescriptive texts may not describe reality, they do provide the cultural images that both shape and reflect extratextual realities. People "experience" through learned systems of meanings; men and women interpret the events of their lives within the context, and through the filter, provided by discourse. Bale's historical writing, itself a way of organizing experience, participated in the broader cultural production of sexualized identities and gender discourse. His work suggests that this discourse was not as straightforward as is often assumed. ${ }^{12}$

Elaine Beilin studied a body of Renaissance women's writings, including those of Anne Askew and the Princess Elizabeth, and suggested that while these texts largely acknowledge women's traditional place, some offer "a redefinition of the importance and domain of the feminine virtues."13 Bale's writings also participate in this renegociation of the terms and meanings of sexual difference. Through his direct admonitions, use of feminine allegory and, primarily, his presentations of exemplary women in the context of apocalyptic history, he responds and contributes to the prescriptive discourse of gender.

Bale suggests that both men and women are equally corrupt before God, and can become equal members of Christ's body. In this regenerated state, the same virtues were expected of both. ${ }^{14}$ As members of the true church, women are held up as examples to both male and female. He suggests that Christ's elect must be strong yet meek, patient but not passive, obedient but not blindly so. He offers not so much a redefinition of accepted female roles as a fluid situation in which women may be required to assume behaviors typically seen as masculine. Perhaps of greater significance, he argues that for women properly to discharge their duties as Christ's members, they must be learned; this learning would be for the benefit not only of the woman and her family, but for Christendom as a whole. ${ }^{15}$

* * *

To understand the position women would assume in Bale's historical thinking, one must first trace the emergence of his ideas. Bale's historical thought evolved gradually, and found expression in an array of genres not usually labeled as "histories." He began his career as a Carmelite friar and apologist. Traveling throughout England and the Continent, he collected the literary monuments and antiquities of his order and wrote biographies and hagiographies of its members. ${ }^{16}$ Around 1534 , he left the monastic life and espoused 
reformist doctrine. Bale then worked, for a time, with the antiquarian John Leland and wrote protestant dramas under the patronage of John Vere and Thomas Cromwell.

These plays, only five of which are extant, reveal the nascent stirrings of Bale's protestant understanding of history. King Johan, by far the most famous of his dramas, is commonly recognized to be the first "history" play; the four others, however, also use figures from sacred history to promote reformed beliefs. ${ }^{17}$ The plays show Bale beginning to rework the tropes of the traditional hagiographies that had preoccupied his Carmelite years, and learning to use exemplary figures in the presentation of historical ideas. Bale's King John becomes a tragic, long-suffering victim of the grasping papacy, and a cautionary figure for King Henry. ${ }^{18}$ The potent imitatio Christi of protestant suffering and martyrdom is emphasized in two of the other plays: the Three Lawes and Temptation of Christ.

Bale had already been examined and briefly imprisoned by the ecclesiastical authorities when these plays were written. His interest in explaining the tribulations of the godly was heightened when, after Cromwell's fall, he was forced into exile. From the Continent, he turned from the use of the dramatic to the printed medium to spread his views. His reliance on Scripture for the precedents and figurae of sacred history, demonstrated in the plays, widened to include an interest in biblical prophecy. The product was the Image of Both Churches. A lengthy verse by verse commentary on the Revelation of Saint John, it was first published in 1545 in three parts that explain the first ten, middle seven, and final five chapters of the Revelation respectively. ${ }^{19}$ This commentary offers a new understanding of the past; Bale writes that history from Adam to Christ is divided into six ages and that "[s]ince Christ's ascension hath the church continued by six other ages of much less time, comprehended in the six seals, in the latter end of whom we are now" (Select Works, p. 449). He interprets the seven seals as seven historical periods, and relates sequentially the concurrent historical implications of the seven trumpets and vials. For Bale, the prophecy of Saint John

is a full clearance to all the chronicles and most notable histories which hath been wrote since Christ's ascension, opening the true natures of their ages, times and seasons. He that hath store of them and shall diligently search them over, conferring the one with the other, time with time, and age with age, shall perceive the most wonderful causes. For in the text are they only proponed in effect ... but in the chronicles they are evidently seen by all ages fulfilled. Yet is the text a light to the chronicles, and not the chronicles to the text (Select Works, p. 253). 
Accordingly, Bale provides the historical clarifications and examples necessary to flesh out the apocalyptic prophecy. Central to this project is a rhetoric of suffering and martyrdom, and a typology of true sainthood. Bale admonishes, "[h]e that knoweth not this book, knoweth not what church whereof he is a member" (Select Works, p. 252).

While it seems clear that Bale intended his typology of the godly to apply to both male and female, he rarely makes this explicit in the Image. In one passage, he does refer to "men, in whom also are included women by the common usage of the scriptures" (Select Works, .p. 492). His lists of righteous exemplars are, however, almost entirely comprised of male historical figures. ${ }^{20}$

Bale would continue his discussion of the nature of the true church, its members and its martyrs. He had elaborated his apocalyptic periodisation of history; the next step was to flesh it out with more elaborated examples both past and present. His first extended effort to recast the hagiographical genre that had so preoccupied his Carmelite days dealt with the life of the Lollard Sir John Oldcastle. This effort proved unsatisfactory, however, for try as he might Bale could not write the fact that Oldcastle was also a traitor out of the historical record. But soon after the publication of the Oldcastle story, Bale received a first-hand account of the interrogations of a contemporary martyr, Anne Askew. ${ }^{21}$ This material allowed him to present a moving story of the beliefs, sufferings and death of one of the elect. Askew's story enabled Bale to create a protestant martyrology unimpeded by recantations or treason. Significantly, it also permitted him explicitly to include women in the history he had crafted for the church.

The daughter of a respectable Lincolnshire knight, Askew held protestant convictions that brought her into conflict first with her husband, then with the authorities. She was arrested in March 1545 under the Six Articles Act, examined by Bishop Bonner and released. Undaunted, she continued to spread her beliefs among the ladies at court and was summoned to appear before the Privy Council on 24 May 1546. Her lively wit, thorough understanding of Scripture and fearless responses stymied her accusers. She was condemned as a heretic, then tortured in the hope that she would implicate her friends at court. Askew held firm, however, in both her beliefs and her silence and was burned at Smithfield on 16 July 1546.22

Bale's work consists of Askew's account of her interrogations interspersed liberally with his own commentaries and explanations. The Examinations of Anne Askew deals with a contemporary martyr, but relies on 
historical comparisons and arguments to portray her as one of a line of persecuted saints that ran from the present back to the time of Christ. Bale makes this approach particularly clear with the subtitle added in the second edition of the First Examination: "The Censure of Judgement of John Bale Thereupon, After the Sacred Scriptures and Chronicles" (Select Works, p. 147). ${ }^{23}$ Bale's concern throughout is to define true martyrdom and place his subject firmly within that tradition. His commentary endeavors to prove the scriptural basis of Askew's beliefs and serves the dual purpose not only of doctrinal exposition but also of validating Askew as a martyr. This is reinforced with the typological identification of Askew with the early church martyr, Blandina. In the preface to the First Examination, Bale compares point by point the ecclesiastical historian Eusebius' account of the young Blandina with Askew's life (Select Works, pp. 141-144). He concludes that Askew "was no less fast a member of Christ ... than was the aforenamed Blandina in the primitive church" (Select Works, p. 147).

In the preface to the Latter Examination Bale lists various writers, from Saint Luke to Nicephorus, who had collected the stories of martyrs, both to honor them in continual remembrance and to hold them up as examples. After he establishes early church writers as his models, he explains that of the English canonized saints, only those of the pre-Augustinian church are true. Until Augustine's mission in 597, the British church was undefiled; after that time there were two kinds of martyrs: "monastery builders," often executed by the secular authorities for manifest treason, and "preachers of the gospel," generally murdered by the institutional church (Select Works, pp. 188-189). Bale then scathingly recounts the stories of dozens of English saints and the often comical, but never saintly, causes of their deaths. He suggests that if even the best of these, such as St. Edmund of Bury, St. Oswald of Gloucester and St. Winstan of Evesham, were brought to the touchstone of the gospel, their martyrdoms would be found "full unlike to theirs whom the bishops murder now apace in England" (Select Works, pp. 192-193). Bale uses this litany of false saints to mock Catholic ceremonies, relics, greed, celibacy and desires for temporal authority, but also to define by opposition the true saint. He asks his readers to compare Askew's life to those of the pope's martyrs:

I would but know of them which are common readers of chronicles and saints' lives, where they ever read of a more fervent and lively faith than was in this godly young woman (Select Works, p. 228)? 
Bale again compares his subject's examination and death to those of Christ; he uses the names Caiaphas and Ananias interchangeably for those of Askew's interrogators, Sir Thomas Wriothesly and Sir Richard Rich. ${ }^{24}$ Indeed, Bale compares Pontius Pilate to Askew's examiners and concludes that the former was by far the holier (Select Works, pp. 241-243). The king is absolved of blame for Askew's trials; Bale's attacks are saved for the evil counselors, especially Sir William Paget, Bishop Nicholas Shaxton, and Bishop Stephen Gardiner.

Although Bale would continue to use life-writing as a form of historical exposition, his account of Askew's death was the culmination and highlight of his martyrologies. It is important to note that Bale's martyrologies diverge markedly from the hagiographical tradition and are not simple substitutes for Catholic saints' lives. ${ }^{25}$ Bale borrows some of the forms and functions of medieval hagiography, but his final product is significantly different. The attack on the saints of old had begun under Thomas Cromwell; Bale created, not new saints, but new heroes to fill the void. ${ }^{26}$ His martyrs, like their saintly equivalents, are meant to encourage by example and show the power of the divine in times of trouble. As Bale writes, they serve "to admonish Christ's flock by this present revelation of their perils past" (Select Works, p. 255). However, his martyrs are examples, but never mediators. They are elect, but never extraordinary. He uses an old form for new purposes, and thus changes that form completely. He combines elements from the hagiographies, biblical commentaries and chronicles not to replace the saints, but repudiate them and the institution for which they died. He places his subjects in the tradition of the sufferings of the primitive church martyrs rather than of the medieval hagiographies. Like Eusebius and the other early martyrologists, Bale too was fighting against the charge of novelty and religious innovation. With his repeated allusions to Christ's death, he establishes a tradition for the new church that goes back to the very beginnings of Christianity.

With his treatment of Anne Askew, Bale explicitly includes women in this new tradition. Protestant women could look to his work and find a history that contextualized not only their church, but their involvement in that church as well. But what exactly is Bale's picture of a godly woman who exemplifies virtues worthy of emulation? The rhetoric and intent of his martyrologies differ from those of the hagiographies; do the lessons to be learned differ as well?

Anne Askew and the three men who joined her in the Smithfield fires are praised equally for their noble virtues. Askew, although "young, dainty 
and tender," is possessed of a "lofty courage" and "strong stomach" (Select Works, pp. 140-143). Bale does, as Beilin suggests, make much of Askew as a "weak woman made strong by God," but it is a physical rather than emotional frailty that she exhibits. ${ }^{27}$ Bale uses her bodily weakness, aggravated by the poor food and violent handling she received while imprisoned, to highlight both the unnatural cruelty of her examiners and the power of God's grace. It is clear, however, that Bale expects women to be capable of the same emotional, spiritual and mental strength as their male counterparts. (Select Works, pp. 193, 209-210, 215-217). Askew, like any good Christian, was gentle and humble where deference was due, but bold and forthright when necessary. Such virtues have their place, but as Bale writes in answer to those offended by the vehemence of the protestants:

I would fain know of them, what modesty they would use (as they call it) if they were compelled to fight with dragons, hydras, and other odible monsters; how patient they would be, and how gentle, if a ravenous wolf came upon them, they having able weapons to put him aside. Surely I know of no kind of charity to be shewed to the devil (Select Works, p. 182).

Her patient virtue and dedication to the Scriptures made Askew a godly woman. When she publicly asserted her beliefs and learning, she died a horrible death; according to Bale, this death was not a punishment, but a sure sign of the highest heavenly reward. ${ }^{28}$ Bale's depiction of Askew is intended as an exemplar for both men and women; the traditional "womanly" virtues become ones to which any good Christian should aspire, but so too do typically "manly" attributes or behaviors.

The virtue of obedience posed a problem for Bale and his fellow reformers. In theory, women were to remain obedient to their husbands, just as Christians were enjoined to submit to the magistrates. In practice, this was complicated by the existence of ungodly husbands and rulers. Obedience must continue in all matters save religion and defense of the Word, but when one's Christian duty and obligations to secular authorities come directly into conflict, Bale offers nothing more than a poorly outlined form of passive resistance. He tries to absolve the ruler of blame by attacking the "evil clerical counselors" and, then, promptly avoids the issue. He took a similar approach in his account of Askew's marital difficulties. Her father had basically sold her into a marriage against her will. Nevertheless, she behaved as a proper Christian wife and bore two children. She would not, however, submit to her husband's wishes that she return to the Catholic faith. This dilemma was solved, to her mind, by Paul's instruction that a faithful woman 
could leave an unbelieving husband. She thus sought a legal divorce, believing herself already freed from the marriage. Bale does not seem entirely comfortable with this justification, for he highlights the fact that it was an improper marriage to begin with and that her husband had forced her out of their home into a form of exile (Select Works, pp. 198-199). Bale believed that duty to the heavenly spouse or lord outweighed that due to the temporal, but suggested that one could only bear patiently the penalties inflicted for disobedience and await a heavenly reward (Select Works, p. 224).

To discharge their duties as Christ's members, Bale suggests that women must be learned in the Scriptures and unafraid to share by example and word the light of the gospel. Askew disputes doctrine with the highest clerical authorities in the land; Bale delights in the witty, careful answers she gives her interrogators. At one point, the bishop's chancellor rebukes Askew for defying Saint Paul's command that women not speak or talk of the Scriptures. She corrects him, saying that Paul only forbade women from preaching in the church and thereby assuming mastery of a congregation. Bale elaborates at length on her correction of this "unlearned chancellor":

Many godly women, both in the old law and the new, were learned in the scriptures, and made utterance of them to the glory of God, as we read of Elizabeth, Mary and Anna the widow, Luke i. and ii.: yet they were not rebuked for it...In the primitive church (specially in St. Jerome's time) was it a great praise unto women to be learned in the scriptures. Great commendation giveth our English chronicles to Helena, Ursula, and Hilda, women of our nation, for being learned also in the scriptures. Such a woman was the said Hilda as openly disputed in them against the superstitions of certain bishops. But this chancellor, belike, chanced upon that blind popish work, which Walter Hunt, a white friar, wrote fourscore years ago, Contra Doctrices Mulieres, against schoolwomen, or else some other like blind Romish beggaries (Select Works, pp. 155-156).

Bale commends Askew not only for her learning and quick answers, but also for her wisdom in recording her interrogations and having them spread abroad (Select Works, p. 147). Because of her prudence, her sacrifice will not have been in vain. Her death and the account of her trials, Bale writes, will convert others and fortify those, both male and female, who might waver in the face of tribulation (Select Works, pp. 243-246).

Retha Warnicke has suggested that the account of Anne Askew's martyrdom did in fact serve to strengthen the resolve of protestant women. During the Henrician reaction, sixty to seventy reformers were burnt as heretics; only four or five of these were women. In contrast, of the 274 Marian martyrs discussed by Foxe, 55 were women. Warnicke speculates that the prominence among the Henrician martyrs of a woman so tenacious, 
educated and quick-witted as Anne Askew led to the larger proportion of women among those killed under the Catholic restoration. ${ }^{29}$

Certainly, writings by apologists of the Marian settlement demonstrated a concern that "martyrs" such as Anne Askew were having a damaging effect. James Cancellar includes a spirited attack on "that presumpteous heretike" and "mad harehead," John Bale, in his Pathe of Obedience. Cancellar was particularly incensed by Bale's identification of his own and other reformers' experiences with those of biblical figures. Belittling Bale's talk of "God's deliverance," he portrays protestant "martyrs" as nothing more than disobedient criminals who threatened the good order of the realm. He discusses "true martyrs," and contemptuously notes that "I meant not here of those Heretikes that latelye have been justly burned for their heresies." 30

Miles Hogarde, in The Displaying of the Protestants, provides a more direct attack on the reformed "martyrs" and their encomiasts. ${ }^{31}$ He labours to discredit the argument that a death valiantly faced signifies a just cause. He cites Bale's treatment of Sir John Oldcastle for, despite Bale's best efforts to prove otherwise, everyone knew that Oldcastle had earned his brave death by actively conspiring against his king. ${ }^{32}$ Hogarde reserves special scorn for the female heretics. He acknowledges the strength of women reformers and the power they could exert to "allure their husbands to dye in the lordes veritie," but suggests that some of these wives wanted nothing more than to replace an old mate with a new. ${ }^{33}$ Even those with nobler goals were simply mislead, for women could not truly know God: "For they bee ever learnyng, and never hable to attaine unto the truth." 34 Hogarde, like Bale, comments on the Pauline injunction that women remain silent in the church. He writes that these "wicked doughters of heresie, and dames of the devil," unhappy with their lot upon finding that "they may not preache, they are contented to burne." There had been genuine female martyrs, but they were of a very different nature than the women now pretending to that role, curious in matters that do not concern them and prattling off scriptures they could never fully understand. He attacks Bale head-on by reciting a list of historical women who were "worthy of immortall fame and vouchsafed to have their images to be erected of golde for their perpetual fame." $35 \mathrm{He}$ changes from a discussion of women to a direct address to his female readers, and sums up the lessons to be learned from his litany of godly women in history: "You ought rather, as I sayd before, to spend your life for the savegarde of your husbandes, and the defence of your chastitie, the bande of matrimonye, as many good wemen have done in tyme past." Hogarde is clearly advocating 
purely "traditional," submissively passive roles and virtues for the women in his audience. It is just as clear, however, that he is trying not only to keep women in their place, but to pull back ones who had already left.

The potential impact of godly role models, and the usefulness of historical figures as examples upon which to pattern a life, were widely recognized in Reformation England. The exemplary martyr would, it was hoped, not have to be imitated to the point of death, but could provide a guide for daily life and a blueprint of virtues to be followed. Nor, of course, did the exemplary figure need to be a martyr; this just strengthened the emotive appeal. Certainly, it has long been recognized that these were the reasons used to encourage men to study histories. It has been less often acknowledged that women were to use histories to the same effect. Thomas Salter expressed such a view in his 1579 guide for female conduct, $A$ Mirrhor mete for all Mothers, Matrones and Maidens:

... our wise matrone shall reade, or cause her maidens to reade, the examples and lives of godly and vertuous ladies, whose worthy fame and bright renowne yet liveth, and out of the holy Scripture, and other histories, both auncient and of late dayes; which bookes will not only delight them, but as a spurre will pricke and incite their hartes to follow virtue $\ldots{ }^{36}$

F.J. Levy suggested that one of the primary differences between medieval and Renaissance histories lie in their didactic intent. The former were to teach personal morality and demonstrate the operation of the divine in daily life, whereas the latter would provide a guide for the assumption of an active role in society. ${ }^{37}$ Bale, firmly grounded in the medieval habits of his monastic forebears but influenced by Polydore Vergil and the emerging trends of humanist rhetoric, sought to combine these didactic impulses for a general audience of both men and women. Unlike Vives and other writers of conduct books who argued that while women should be educated, their learning must not be displayed outside of the family, Bale did not argue that women should remain demurely silent. ${ }^{38}$ With Anne Askew, Bale provided an exemplar of a woman who actively participated in the religious politics of her time; with Elizabeth, he argued that women might also be capable of participating in affairs of state and the general wellbeing of the realm.

In 1548, Bale published the Princess Elizabeth's translation of Marguerite de Navarre's Le Miroir de l'âme pécheresse. Retitled the Godly Medytacyon of the Christen Sowle, this work praises Elizabeth as a learned and godly helpmate to the young King Edward in the current struggle against the evil of the Roman church. It might also, as John King suggests, offer 
indirect support for Elizabeth's stepmother, Catherine Parr, and the protestant ladies of her circle. ${ }^{39}$ The poem itself explains the deliverance of the soul through a complex web of familial relationships and gendered metaphors. ${ }^{40}$ In his dedication and conclusion, Bale presents the work as the fruit of a young, learned Christian woman, and uses it as an excuse to describe nobility and the famous women who exemplified this trait throughout English history. ${ }^{41}$

Bale begins this history with Japhet, Noah's son and the father of the first inhabitants of the British isles. ${ }^{42}$ In this period, nobility was derived from birth and blood, bravery and military prowess, courteous manners, liberality, learning and wisdom (Elizabeth's Glass, p. 84). Then emerged the "monstrous nobility" of the Roman clergy who sought to exalt themselves through ceremonies, deceitful tricks and elaborate costumes. This "nobility digged out of the dunghill" endeavored to subvert and duplicate the dignity properly attained through blood and learning (Elizabeth's Glass, pp. 84-85). Bale then cites Chrysostom and Seneca in support of the idea that true nobility is attained and manifested through a life of virtue; he notes, "[c] hiefly appertaineth it to men and women of sincere nobility to regard the pure doctrine and faith" (Elizabeth's Glass, 86). Bale assures Elizabeth that she and her brother partake of this nobility. How does he know? By the fruit of their godly actions and learned words. Certainly, Elizabeth received the status of nobility through her blood, but this is augmented daily by her pursuit of wisdom and education. Bale's praise for Elizabeth is overwhelming, as is usual for a dedication, but it is significant that he concentrates almost entirely on her learning and studiousness. Furthermore, she is no "niggard over the treasure of God," as are the priests and monks, but shares it liberally with those around her (Elizabeth's Glass, pp. 88, 94).

Nor is Elizabeth an exception, for there are "many other noble women and maidens more in this blessed age." Indeed, "no realm under the sky hath had more noble women, nor of more excellent graces, than hath this realm of England, both in the days of the Britons and since the English Saxons obtained it by valiant conquest" (Elizabeth's Glass, pp. 88, 97). From Gwendolyn, wife of the second king of Britain, and Cordelia, daughter of Lear, Bale discusses the famous women who lived in England from its first settlement to the present. Many of these women ruled, whether in their own names or as regents. Others, as wives, sisters or daughters of kings, used their wisdom and learning to the benefit of the commonwealth through military strength, lawmaking, building, agriculture, education and the exam- 
ple provided by their good graces, love and virtue. These women are praised for their beauty, but are no simple ornaments. They have been given talents by God and use them appropriately. They are identified by their relationships to men, but their nobility is a function of their own God-given virtues and achievements, not those of their fathers or sons. They are praised for a wide range of virtues and actions that might usually have been gendered male or female (Elizabeth's Glass, pp. 97-100). ${ }^{43}$

Bale assures his readers that although "none in this land have yet ... left behind them catalogues or nomenclatures of famous and honourable women, yet hath it not at any time been barren of them" (Elizabeth's Glass, p. 101). And now, in this age, with Christ's doctrine freed from popish superstitions and available to all, the virtues attendant on nobility are manifest in many more women. He points again to the strong spirit of Anne Askew who, as "Christ's mighty member," was victorious over the forces of Satan. Her nobility derived not from blood and inheritance, but from Christ's mighty living spirit. Bale praises the examples provided by both Anne and Elizabeth, and enjoins other women to emulate these noble ladies. Just as women "are become glorious to the world by the study of good letters, so may they also appear glorious in His sight by daily exercise in His divine scriptures" (Elizabeth's Glass, pp. 101-102).

It is tempting to put this work in the context of the debates over the propriety of female rulers. Warnicke discusses the attacks on female monarchs, and the legal, moral and theological arguments used to justify queenly rule. She writes that the reigns of Mary and Elizabeth would change the constitutional climate in such a way that dynastic history would be rewritten to support the claims of female rulers. ${ }^{44}$ Amussen suggests, in contrast, that Elizabethan antiquarians would reject the applicability of ancient British queens as precedents and thereby identify Elizabeth as an exception to the preferable state of male rule and general worth of women. ${ }^{45}$

Bale, however, wrote these works before either Mary or Elizabeth came to the throne, and a full ten years before Knox issued his First Blast of the Trumpet Against the Monstrous Regiment of Women. Not yet confronted by an actual female ruler or writing in response to any debate over the legitimacy of female rulers, Bale recites a list of women who governed throughout history. He feels no need to justify their existence or the legitimacy of gynocracy, nor does he imply that they were exceptional. Instead, he offers examples of women who contributed to the good governance of the commonwealth and, thus, reasons why the participation of women should con- 
tinue. Perhaps the fact that he took this legitimacy for granted is just as illuminating about ideas regarding women as is the language of justification used by later writers. Certainly, in his own later writings when he is faced with the issue of the proper obedience due to Mary, his questions are based on her religion rather than her gender. ${ }^{46}$

Although Bale's arguments cannot be directly applied to a debate in which he did not participate, they are instructive. He suggests that women, as spouses of Christ, can attain a nobility of spirit that makes them worthy of participation in the affairs of the commonwealth. While this legitimacy is a function of a woman's relationship with a male figure, it is a spiritual rather than temporal marriage that confers power.

Bale presents Anne Askew and the Princess Elizabeth as agents in the struggle of the two churches, and thus openly includes women in the rewritten version of England's history. This historiography, with its presentation of exemplary figures, portrays a modified picture of the "godly woman": learned in the Scriptures, living a life of humble virtue, but willing to assume a public stand in defense of the Word. Both implicitly and explicitly - by publishing the works of these two authors, and by praising them for their noble Christian charity in presenting their works to the public - Bale advocates an active voice for women in the Reformation.

Bale's version of the Godly Medytacyon had only one edition. The Image and First Examination of Anne Askew had five, and the Latter Examination had four. ${ }^{47}$ It has been estimated that there were anywhere between 600 and 1,500 copies in an average sixteenth-century edition; by even the more conservative figure, a significant number of copies were produced. ${ }^{48}$ They were, for the most part, published while Bale was in exile, but he and his fellow reformers seem to have had little difficulty in evading the import restrictions and censorship laws. All but one of these editions were printed in the relatively cheap octavo format and were most likely within the purchasing range of at least a middling readership. Women unable to read were not necessarily precluded from a familiarity with Bale's injunctions to increase their learning; vocalized or communal reading was common, as Bale acknowledges in the Image when he admonishes all to "receive the words of this wonderful prophecy here written in this book, whether by reading or hearing" (Select Works, p. 612). ${ }^{49}$ Many women could thus have come into contact with Bale's ideas. How they as individuals would appropriate and receive these ideas is, unfortunately, difficult to recapture. 
Textual reception is a dynamic, interactive process. Efforts to recreate the individual or aggregate response to a work immediately face the difficulties imposed by artificially trying to separate prescription from description, language from experience, and written text from lived reality. Did some women assume the role in apocalyptic history that Bale had envisioned for them? Certainly, but when discussing the degree to which some women were motivated by ideas such as Bale's, it must be remembered that his writings were themselves formulated in response to the female reformers who patronized, published and contributed to them.

John Foxe's much read work was influenced by Bale's martyrologies and apocalyptic periodization of history. Does Foxe's epic history reveal the same ambiguity about gender roles and behaviors as Bale's work? Or does it present a more refined picture of the godly woman and her role in the reformed church? As we seek to understand how women will fit into the histories we write for ourselves, perhaps we should examine the politics and perceptions that shaped the inclusion or exclusion of women in the historical writing of the past.

Queen's University

\section{Notes}

1. John Bale, The first examinacyon of Anne Askew and The lattre examinacyon of Anne Askew, first published in 1546 and 1547 respectively. The first combined version came off the presses in 1547 (STC \# 851). Citations from Examinacyons in this paper come from the Parker Society's Select Works of John Bale, ed. Henry Christmas (New York: Johnson Reprints, 1968 [1849]), which used the 1547 combined version. Bale, A Godly Medytacyon of the christen sowle ... translated into Englysh by the ryght vertuouse lady Elizabeth (STC \# 17320, 1548). Citations are taken from Marc Shell's transcription in Elizabeth's Glass (Lincoln: University of Nebraska Press, 1993). For works that study the Examinacyons and the Medytacyon as examples of women's writings, see Shell; Elaine V. Beilin, Redeeming Eve: Women Writers of the English Renaissance (Princeton: Princeton University Press, 1987); and Anne Lake Prescott, "The Pearl of Valois and Elizabeth I: Marguerite de Navarre's Miroir and Tudor England," in M. P. Hannay, ed. Silent but for the Word: Tudor Women as Patrons, Translators and Writers of Women's Works (Kent: Kent State University Press, 1985), pp. 61-76.

2. One exception is Thomas Betteridge's "Anne Askew, John Bale and Protestant History," Journal of Medieval and Renaissance Studies, 27 (1997): 265-284, which looks at the cultural tensions between Askew's words and Bale's while arguing for a continuity between Askew's sixteenth century text and works of earlier religious radicals.

3. For two studies of the uses of gendered metaphors in Bale's work, see Claire McEachern, "A Whore at the first blush seemeth only a woman': John Bale's Image of Both Churches 
and the Terms of Religious Difference in the Early English Reformation," Journal of Medieval and Renaissance Studies, 25 (1995): 244-269; and Jacqueline Vanhoutte, "Engendering England: The Restructuring of Allegiance in the Writings of Richard Morrison and John Bale," Renaissance and Reformation, 20 (1996): 49-77.

4. See Rainer Pineas' series of articles on Bale, especially "William Tyndale's Influence on John Bale's Polemical Use of History," Archiv fur Reformationsgeschichte, 53 (1962): 79-96. Peter Happé provides a useful summary in "Recent Works on John Bale," English Literary Renaissance, 17 (1987): 103-110. See also Leslie Fairfield, John Bale: Mythmaker for the English Reformation (West Lafayette: Purdue University Press, 1976), and this author's unpublished thesis, "John Bale's Use of History," Dalhousie University, 1995, pp. 2-4. For general works on Tudor historiography, see F. J. Levy, Tudor Historical Thought (San Marino: Huntington Library, 1967); T.D. Kendrick, British Antiquity (London: Methuen, 1967); F. Smith Fussner, Tudor History and the Historians (New York: Basic Books, 1970); Arthur Ferguson, Clio Unbound (Durham: Duke University Press, 1979); May McKisack, Medieval History in the Tudor Age (Oxford: Clarendon Press, 1971); and D. R. Woolf, "Genre to Artifact: The Decline of the English Chronicle in the Sixteenth Century," Sixteenth Century Journal, 19 (1988): 321-354.

5. Annabel Patterson, in two recent works, effectively disproves the notion of a historiographical wasteland in the sixteenth century and suggests that the works of Tudor historical writers might richly repay careful analysis. See "Rethinking Tudor Historiography," South Atlantic Quarterly, 92 (1993): 185-208; and Reading Holinshed's Chronicles (Chicago: University of Chicago Press, 1994).

6. See Kesselring, “John Bale's Use of History," passim.

7. Bale, Brefe Chronycle concernynge ... Syr J. Oldcastell (STC \# 1276, first published 1544); The Vocacyon of Johan Bale (STC \# 1307, 1553) has been edited by Peter Happé and John King, and published by the Renaissance English Text Society (Binghamton, 1990). See also Fairfield, "The Vocacyon of John Bale and Early English Autobiography," Renaissance Quarterly, 24 (1971): 327-340.

8. Actes of the Englysh Votaryes (STC \# 1270, first published 1546), Acta Romanorum Pontificum (1558). In 1574, the latter was "Englyshed with sondrye additions" by John Studley as the Pageant of Popes (STC \# 1304). The Votaryes relies heavily on Capgrave's Legenda Sanctorum; the Acta Romanorum Pontificum draws from fellow reformer Robert Barnes' Vitae Romanorum Pontificum and Bartolomeo Platina's De Vita et Moribus Summorum Pontificum, all well-known examples of medieval/early modern life-writing. On life-writing in general, see the introduction to The Rhetorics of Life-Writing in early Modern Europe: Forms of Biography from Cassandra Fedele to louis XIV, eds. Thomas F. Mayer and D.R. Woolf (Ann Arbor: University of Michigan Press, 1995): 1-38.

9. John Bale, Illustrium maioris Britannie Scriptorum ... Summarium (STC \# 1295, 1548); Scriptorum illustrium maioris Britannie ... Catalogus (1557); Posterior Pars (1559). See Kesselring, “John Bale's Use of History," pp. 80-102; Fairfield, Mythmaker, pp. 88-116, also pp. 8-10 for Bale's early work as Carmelite friar, writing saints' lives and Carmelite biobibliographies. 
10. Carole Levin, in a brief but suggestive article, looks at Foxe's stories of women martyrs as examples of prescriptive literature. She writes that although Foxes's messages could be contradictory, they for the most part reinforced the traditional female virtues of modesty, humility, sweetness and piety: "Women in the Book of Martyrs as Models of Behavior in Tudor England," International Journal of Women's Studies, 4 (1981): 196-207. See also Rheta Warnicke's "Eulogies for Women: Public Testimony of the Godly Example and Leadership," in Attending to Women, eds. Betty S. Travitsky and Adele F. Steele (London: Associated University Presses, 1994), pp. 168-186 for an interesting discussion of funeral sermons for women as exemplars for both sexes, and a suggestive use of these speeches for evidence of successful socialization.

11. For an introduction to the prescriptive texts and to the querelle des femmes, see Suzanne Hull, Chaste, Silent and Obedient: English Books for Women, 1475-1640 (San Marino: Huntington Library, 1982), which describes the works and the nature of their female audience; and Linda Woodbridge, Women and the English Renaissance: Literature and the Nature of Womankind, 1540-1620 (Brighton: Harvester, 1984), which justly warns that texts may be significant as rhetorical arguments while not reflecting the actual views of the writer. For a work exploring the significance of gender distinctions in religious history (although it concentrates on the Civil War period), see Patricia Crawford, Women and Religion in England, 1500-1720 (London: Routledge, 1993). An older, but still helpful, survey of the field can be found in Merry E. Wiesner's "Beyond Women and the Family: Toward a Gender Analysis of the Reformation," Sixteenth Century Journal, 18 (1987): 311-21. For the lively epistemological debate between empiricists/social historians and discourse scholars, a convenient introduction is provided by Susan Amussen's "Elizabeth I and Alice Balstone: Gender, Class and the Exceptional Woman in Early Modern England"; and Margaret Ferguson's response in "Attending to Literacy" in Attending to. Women in Early Modern England: 219-40, 265-79.

12. It continues to be assumed that a monolithic prescriptive ideology can be contrasted to a set of differing realities. See Retha Warnicke, art. cit.; and Carole Levin and Jeanie Watson, eds., Ambiguous Realities: Women in the Middle Ages and Renaissance (Detroit: Wayne State University Press, 1987). Women's realities cannot be understood or described as an opposition to a straightforward dogma: even if one does not accept the reflective, mutually constructive relationship of experience and language, it is important to recognize that "reality" mediated between more than one set of prescriptive guidelines.

13. Beilin, Redeeming Eve, p. $\mathrm{xv}$.

14. See Margaret Masson, "The Typology of the Female as a Model for the Regenerate: Puritan Preaching, 1690-1730," Signs, 2(1976): 304-315 for a discussion of how puritan preaching in the colonies encouraged mutually inclusive norms of behavior in certain contexts.

15. Bale is advocating a knowledge of the scriptures and the history of the curch, not the classical learning that Rheta Warnicke studies in her Women of the English Renaissance and Reformation (Westport: Greenwood Press, 1983).

16. Fairfield, Mythmaker, pp. 8-14; Andrew Jotischky, "Gerard of Nazareth, John Bale and the Origins of the Carmelite Order," Journal of Ecclesiastical History, 46 (1995): 214-236. 
17. Kesselring, "John Bale's Use of History," pp. 7-8, 20-25. See also The Complete Plays of John Bale, 2 vols. ed. Peter Happé (Cambridge: D.S. Brewer, 1986).

18. See Carole Levin, Propaganda in the English Reformation: Heroic and Villanous Images of King John (Queenston-Lewiston: E. Mellen Press, 1988) for the ways in which the historical King John was redeemed by a number of writers for protestant purposes.

19. The STC gives (Antwerp, 1545?) as the date for the first edition, STC \# 1296.5. Only parts One and Two of this edition have survived, but as Fairfield notes (Mythmaker, p. 166), the third part must have appeared about the same time because all three were banned by Bonner in September of 1546. The work was probably finished substantially before this date as Bale alludes to it in his Manne of Sin, published in 1543. (sig. A $8^{\mathrm{V}}$ ). Citations in this paper are taken from the Select Works, which uses the first complete edition of the Image, printed in 1548 (STC \# 1297). The Image has received significant attention over the past 20 years. Various scholars, attempting to put the militant millenarianism of the Civil War years into historical perspective, have studied Bale's formative effect on English apocalyptic thought. See Richard Bauckham, Tudor Apocalypse (Oxford: Sutton Courtenay, 1978); Paul Christianson, Reformers and Babylon (Toronto: University of Toronto Press, 1978); and Katherine Firth, The Apocalyptic Tradition in Reformation Britain (Oxford: Oxford University Press, 1979).

20. This is not to say that female figures are absent from Bale's text. The Woman Clothed With the Sun and the Whore of Babylon battle for the souls of the godly; the Whore and the Bride of Christ represent the false and the true churches respectively. These figures became central metaphors in Reformation writing. See above, note 2 and Crawford, Women and Religion, pp. $13 \mathrm{ff}$.

21. See John King, English Reformation Literature (Princeton: Princeton University Press, 1982), pp. 72-73; King suggests that the Duchess of Richmond, later Bale's patron, may have helped smuggle the account to Bale in exile. Bale records that he received it from Dutch merchants who had been present at the burning. (Select Works, pp. 195-196).

22. Biographical information is taken from Fairfield, Mythmaker, pp. 130-131. See also James K. McConica, English Humanists and Reformation Politics (Oxford: Clarendon Press, 1965), pp. 222-227 for an account of the examination in light of Askew's ties to the court and Queen Catherine Parr.

23. This edition, printed in 1547 with marginal notes and a fuller commentary, shows a more careful preparation than was possible with the first, which was published only months after the events it describes.

24. See, for instance, Select Works, pp. 166-167.

25. Bale had long been ignored in studies of protestant martyrologies. Helen C. White, in her important Tudor Books of Saints and Martyrs (Madison: University of Wisconsin Press, 1963), overlooks him completely. William Haller, in Foxe's Book of Martyrs and the Elect Nation (London: J. Cape, 1963), discusses Bale's influence on Foxe's apocalyptic periodization of history, but only briefly comments on the relationship of Bale's martyrologies to Foxe's epic work. Leslie Fairfield was the first to draw significant attention to Bale's works, but he follows too closely White's argument in stressing them as hagiographies and as a 
stepping stone between the Golden Legend and Foxe's later work: "John Bale and the Development of Protestant Hagiography in England," Journal of Ecclesiastic History, 14 (1973): 145-160. Lucia Bergamasco's “Hagiographie et sainteté en Angleterre aux XVI XVIII ${ }^{\mathrm{e}}$ siècles," Annales ESC, 48 (1993): 1053-1085 provides a useful study of the changing functions of saints' lives. John R. Knott's discussion, which builds on Fairfield's, clarifies the differences between hagiography and protestant martyrology, for it studies both Bale and Foxe not in a hagiographical generic tradition, put as a part of a continuing discourse of persecution and suffering: Discourses of Martyrdom in English Literature, 1563-1694 (Cambridge: Cambridge University Press, 1993), pp. 42ff. For a critique of White's "hagiographical" argument, see D.R. Woolf, "The Rhetoric of Martyrdom: Generic Contradiction and Narrative Strategy in John Foxe's Acts and Monuments," Rhetorics of Life Writing, eds., Woolf and Mayer: 243-282.

26. See Rainer Pineas, Thomas More and Tudor Polemics (Bloomington: Indiana University Press, 1969), pp. 112-114.

27. Beilin, Redeeming Eve, pp. 29-31. Select Works, pp. 209, 225, etc.

28. Carole Levin has examined Foxe's account of Askew's martyrdom. She suggests that Foxe's description of Anne's death, earned for refusing a traditional submissive role, was written as a warning and admonition to his female readers not to do the same. While many women might have taken it this way, preferring a long life to some unseen heavenly reward, it seems doubtful that Foxe intended it as such. ("Women in The Book of Martyrs as Models of Behavior in Tudor England," pp. 200-203). In treating death not as a punishment for a life lived in sin, but as the pathway to reward and sign of a godly life, the martyrologies present an interesting inversion of the criminal biographies and pamphlets that would remain consistently popular through this period. For an introduction to this genre, see Peter Lake, "Deeds Against Nature: Cheap Print, Protestantism and Murder in Early Seventeenth-Century England," Culture and Politics in Early Stuart England, ed. K. Sharpe and P. Lake (Basingstoke: Macmillan, 1994), pp. 257ff.

29. Warnicke, Women of the English Renaissance and Reformation, pp. 75-76.

30. James Cancellar, The Pathe of Obedience (STC \# 4564; ?1556), sigs. B8 ${ }^{\mathrm{r}-\mathrm{v}}, \mathrm{D} 3^{\mathrm{r}}-\mathrm{D} 6^{\mathrm{r}}$.

31. Miles Hogarde, The Displaying of the Protestants (STC \# 13557; 1556). On Hogarde, see J.W. Martin, "Miles Hogarde: Artisan and Aspiring Author in Sixteenth-Century England," Renaissance Quarterly, 34 (1981): 359-383.

32. Hogarde, Displaying of the Protestants, sig. $40^{\mathrm{r}}$.

33. Ibid., sig. $77^{\mathrm{r}}$. This branding of religious opponents as sexual offenders was a common form of defamation; Hogarde's attacks pale in comparison to Bale's scathing characterizations of the morality of priests and nuns.

34. Ibid., sig. $76^{\mathrm{V}}$. Significantly, when Hogarde goes on to discuss protestant members of the episcopacy who were also "ever learning and never able to come to the truth," the bishops are described as "effeminate." (sig. $80^{\mathrm{V}}$ ) Thus, for Hogarde, the inability to be properly "learned" was not limited to women, but is was a gendered, female trait.

35. Ibid., sig. $78^{r}-80^{v}$. 
36. Thomas Salter, A Mirrhor mete for all Mothers, Matrones and Maidens (STC \# 21634; 1579), sigs. B2 ${ }^{\mathrm{v}}-\mathrm{B} 3^{\mathrm{r}}$. See Louis B. Wright, "Reading of a Renaissance English Woman," Studies in Philology, 2 (1931): 671-688.

37. Levy, Tudor Historical Thought, pp. ix-xi.

38. Valerie Wayne, "Some Sad Sentence: Vives's Instruction of a Christian Woman," Silent but for the Word, ed. Hannay: 15-29.

39. See John King, "Patronage and Piety: The Influence of Catherine Parr," Silent but for the Word, ed. Hannay, p. 51.

40. Anne Lake Prescott, "The Pearl of Valois and Elizabeth I: Marguerite de Navarre's Miroir and Tudor England," Silent but for the Word, ed. Hannay: 61-76, studies the work for what it reveals of Elizabeth's reactions to her troubled upbringing. Marc Shell approaches the poem for similar purposes in his Elizabeth's Glass. Beilin explores the female scriptural allegories that run through the poem, and discusses its inclusion in Thomas Bentley's Monument of Matrons (1582); Bentley's work includes the writings of women of "al ages" and seeks to educate women in their long spiritual history. (Beilin, Redeeming Eve, pp. 64-72).

41. After Elizabeth's succession to the throne, James Cancellar renounced the views he had so ardently expressed as a supporter of Mary's Catholic reign. He attempted to curry favor by publishing his own edition of Elizabeth's translation in 1568. It would be instructive to compare his introductory comments to Bale's: unfortunately, a complete copy of Cancellar's edition is not immediately available. STC \# 17320.5 is missing the title page, dedication and preface; STC \# 17321 (=17322) does not seem to be in the UMI collection of Early English Books. See Ruth Hughey, "A Note on Queen Elizabeth's 'Godly Medytacyon,"” The Library, $4^{\text {th }}$ ser., 15 (1935): 237-240 for a publication history of this work. Besides the more immediate importance of comparing how these two men present the female author in their glosses on the text, it would be interesting to see how the personal animosities of Bale and Cancellar played themselves out. In response to Cancellar's attack in the Pathe of Obedience, Bale had attempted to publish a work that included a scathing picture of the converted Catholic apologist. See E.J. Baskerville, "A Religious Disturbance in Canterbury, June 1561: John Bale's Unpublished Account," Historical Research, 65 (1992): 340-348.

42. In his two biobibliographical histories and the Acts of the English Votaryes. Bale's interest in the history of the pre-Augustinian church widened to include pre-history itself. Not only did Bale support the Brutus and Arthurian legends, but he added another tale to the early annals of British history. Polydore Vergil had criticized the story that the British Isles had been founded by Brutus the Trojan partly on the biblical basis that all nations had been peopled after the Great Flood. Bale was too happy to add an earlier chapter to the story of Britain's foundation, one that gave his island a biblical background in addition to the Trojan. This pre-Trojan population was descended from Samothes, son of Japhet. Bale took his inspiration from Annius of Viterbo's 1498 publication of the supposed writings of Berosus, the Chaldean historian of the age of Alexander the Great. The Samothean history enjoyed a period of popularity, although the text upon which it was based was shown to be a forgery soon after Bale's death. See T.D. Kendrick, British Antiquity, pp. 69-76; and J.D. Alsop, 
"William Fleetwood and Elizabethan Historical Scholarship," Sixteenth Century Journal, 25 (1994): 157-159.

43. He points to the lists written by Plutarch and Boccaccio as examples.

44. Warnicke, Women of the English Renaissance and Reformation, pp. 60-63.

45. Amussen, "Elizabeth I and Alice Balstone," pp. 222-23. See also Constance Jordan, "Women's Rule in Sixteenth Century British Political Thought," Renaissance Quarterly, 40 (1987): 421-451.

46. See, for example, his discussion of the events surrounding King Edward's death and the proclamations first of Jane's, then Mary's rule: Vocacyon, pp. 55-67.

47. "Edition" has been used in the bibliographic sense, and thus these numbers do not reflect variants or issues. Also, it should be remembered that entire editions of sixteenth century works have been lost. For what follows, see Kesselring, "John Bale's Use of History," pp. 103-130.

48. H.S. Bennett, English Books and Readers, 1475-1557 (London: Cambridge University Press, 1969) estimates 600-700, p. 228; Philip Gaskell, A New Introduction to Bibliography (Oxford: Clarendon Press, 1972) suggests 1,000-1,500, pp. 160-162.

49. There has been a substantial amount of work done on the importance of communal reading, but see Margaret Aston's chapter, "Lollards and Literacy," in her Lollards and Reformers: Images and Literacy in Late Medieval Religion (London: Hambledon Press, 1984) for a discussion of its role in the dissemination of ideas in an earlier period of religious reform. 